\title{
EFFECT OF QUALITIES OF SERVICE AND FUNDING PRODUCT ON BRAND IMAGE AND LOYALTY OF SHARIA BANK CUSTOMERS IN BOGOR
}

\author{
Afiatin Dewi ${ }^{*}$, Mukhamad Najib ${ }^{* *}$, and Irfan Syauqi Beik ${ }^{* * *}$ \\ *) Program Study of Islamic Banking, Faculty of Islamic Economics, Djuanda University \\ Jl. Tol Ciawi No1, Ciawi-Bogor, 16720 \\ **) Department of Management, Faculty of Economics and Management, Bogor Agriculture University \\ Jl. Agatis, Campus IPB Dramaga, Bogor 16680 \\ ${ }^{* * *}$ Department of Islamic Economics, Faculty of Economics and Management, Bogor Agriculture University \\ Jl. Agatis, Campus IPB Dramaga, Bogor 16680
}

\begin{abstract}
This research objective is to determine the correlation between service and product qualities and customer's loyalty and brand image of sharia banking in Indonesia. This is a descriptive research whose objects included Bank Muamalat, Bank BNI Syariah, Bank Permata Syariah, and Bank BTN Syariah located in Bogor City. This research used Structural Equation Model (SEM) method as a research analysis tool with 200 customers as the respondents. The proper Sharia Banking's value is not only reflected in terms of service but also in developing products that can compete with conventional banks. The features in the products have provided easiness in transactions for customers and are free from riba. Based on the test, service and product qualities simultaneously have positive effects on brand image, and brand image positively affects the loyalty of sharia banking customers.
\end{abstract}

Keywords: sharia banking, service quality, product quality, brand image, and customer loyalty

Abstrak: Penelitian ini bertujuan untuk mengetahui hubungan kualitas layanan dan kualitas produk terhadap loyalitas dan citra merek banksharia di Indonesia. Jenis penelitian ini adalah penelitian deskriptif dengan obyek penelitian adalah Bank Muamalat, Bank BNI Syariah, Bank Permata Syariah, dan Bank BTN Syariah yang berada di Kota Bogor. Penelitian ini menggunakan metode Structural Equation Model (SEM) sebagai alat analisis penelitian dengan jumlah responden yang diambil sebanyak 200 nasabah. Hasil analisis penelitian ini menunjukkan bahwa bank sharia berada dalam kategori baik yang direpresentasikan dari kepuasan layanan dan kualitas produk. Pelayanan yang diberikan oleh sharia banksudah mulai mencerminkan nilai-nilai syariah yang tidak dimiliki oleh bank konvensioanal dan diharapkan dapat terus mempertahankan dan meningkatkan nilai-nilai tersebut. Berdasarkan hasil pengujian, dapat disimpulkan bahwa kualitas layanan dan kualitas produk secara simultan memiliki pengaruh positif terhadap citra merek dan citra merek berpengaruh positif terhadap loyalitas pelanggan perbankan syariah.

Kata kunci: bank sharia, kualitas layanan, kualitas produk, citra merek, dan loyalitas nasabah

\footnotetext{
${ }^{1}$ Corresponding author:

Email: afiatin.dewi@gmail.com
} 


\section{INTRODUCTION}

Sharia Bank is a bank whose operations completely applies the principles of sharia, and if in the implementation, it is not in accordance with Islamic values, the sharia values of Islamic banks fall down. Islamic banks were founded on the basic value of sharia i.e. divine (revelation), while the conventional bank is the result of human thoughts. According to Antonio (2001), islamic banking has a number of characteristics: the sharia bank in its operation only conducts halal investments, applies the islamic principles for revenue, selling, or renting and does not apply the interest based system, but has profit and falah orientation. The relationship with customers is in the form of partnerships. Collection and distribution of funds should be in accordance with the fatwa of the Sharia Supervisory Board.

The development of sharia banking in Indonesia has become a measurement of the success of the existence of the Islamic economy, and this will affect the management of human resources. Islamic banking does not only need human resources who have expertise and high capability but also requires human resources that have acquired knowledge and adherence to real Islamic values.

Based on Table 1, the Islamic banking industry has evolved significantly in Indonesia characterized by the increase in the total assets of BUS-UUS-SRB from 2012 to 2016 amounted to 165.94 (in Trillion Rupiah). This increase is also characterized by the presence of 12 Islamic banks (BUS), 22 Sharia Business Units (UUS), and 161 Bank Financing Rakyat Syariah (BPRS) owned by Indonesia up to the year 2016 (FSA 2016). This shows that the interest and expectations of the society towards islamic banking services showed an increase. The public wants the presence of sharia banking products to be varied in accordance with the needs and conditions of each customer. These developments provide a positive impact for the community where it is being benefitted with a large of number of choices of products and services offered by Islamic banking.

Table 1. the Development of Islamic Banking from 2012 to 2016 December 2016

\begin{tabular}{lccccc}
\hline Main Indicators & 2012 & 2013 & 2014 & 2015 & 2016 \\
\hline Total of BUS-UUS-BPRS & & & & & \\
Total Asset of BUS-UUS-BPRS & 199.71 & 248.11 & 278.90 & 304.00 & 365.65 \\
Asset growth of BUS-UUS- BPRS & $34.04 \%$ & $24.24 \%$ & $12.41 \%$ & $9.00 \%$ & $20.28 \%$ \\
Market Share & $4.58 \%$ & $4.89 \%$ & $4.85 \%$ & $4.83 \%$ & $5.33 \%$ \\
DPK BUS-UUS-BPRS (Rp Triliun) & 150.447 & 187.196 & 221.890 & 236.020 & 285.15 \\
Growth of DPK BUS-UUS-BPRS & $28.03 \%$ & $24.43 \%$ & $18.53 \%$ & $6.37 \%$ & $20.84 \%$ \\
PYD BUS-UUS-BPRS & 151.063 & 188.553 & 204.310 & 218.725 & 254.65 \\
Growth of PYD BUS-UUS-BPRS & $43.41 \%$ & $24.82 \%$ & $8.35 \%$ & $7.06 \%$ & $16.41 \%$ \\
Total of BUS-UUS & & & & & \\
Asset Total of BUS-UUS (Rp Triliun) & 195.02 & 242.28 & 272.34 & 296.26 & 356.20 \\
Asset Growth of BUS-UUS & $3.064 \%$ & $24.23 \%$ & $12.41 \%$ & $8.78 \%$ & $20.33 \%$ \\
DPK BUS-UUS & 147.51 & 183.53 & 217.86 & 231.17 & 279.33 \\
Growth of DPK BUS-UUS & $27.81 \%$ & $24.42 \%$ & $18.71 \%$ & $6.11 \%$ & $20.83 \%$ \\
PYD BUS-UUS (Rp Triliun) & 147.51 & 184.12 & 199.30 & 212.96 & 248.01 \\
Growth of BUS-UUS & $43.69 \%$ & $24.82 \%$ & $8.24 \%$ & $6.86 \%$ & $16.44 \%$ \\
ROA & $2.14 \%$ & $2.00 \%$ & $0.79 \%$ & $0.84 \%$ & $0.94 \%$ \\
BOPO & $74.97 \%$ & $78.21 \%$ & $94.16 \%$ & $94.38 \%$ & $93.63 \%$ \\
NPF (nett) & $1.34 \%$ & $1.75 \%$ & $2.94 \%$ & $2.77 \%$ & $2.06 \%$ \\
NPF (gross) & $2.22 \%$ & $2.62 \%$ & $4.33 \%$ & $4.34 \%$ & $4.15 \%$ \\
CAR (BUS) & $14.13 \%$ & $14.44 \%$ & $16.10 \%$ & $15.02 \%$ & $16.16 \%$ \\
FDR & $100.00 \%$ & $100.32 \%$ & $91.50 \%$ & $92.14 \%$ & $88.78 \%$ \\
\hline
\end{tabular}


According to Karim (2006) the development of Islamic banking must be supported by human resources both in terms of quality and quantity adequately. This condition is quite significant because of its effect on the productivity and professionalism of Islamic banking because the professionalism of the employees will influence the attitudes of employees to provide service to the customer. The aspect that most distinguishes the conventional system and the sharia system is the fulfillment of adherence to Islamic values (sharia compliance). Ismail (2014) mentioned that the competition occurring in the business world encourages the emergence of creative ideas that can build products and services that will provide satisfaction and value to customers with the expectation the customers will be loyal with the company. Excellent service to the customer is very important because it is one of the strategies to win the competition, and this is called excellent service. Service excellence is a concern to our customers by providing the best service to facilitate the ease, fulfillment, and realization of the satisfaction of the customers so that they are always loyal to the company (Wirtz and Lovelock, 2004).

A Survey conducted by the Havard Business Review, U.S. News and World Report for the loss of customers generated that $14 \%$ of customers left because their complaints were not handled properly, and $9 \%$ of customers left because they were attracted to product offerings from the competitors. Moreover, $9 \%$ of the customers left because they moved out of the city, and as much as $68 \%$ of them left because of the disappointing attitude and service of the employees. These results indicate that the behavior and attitude of the employees of the company become the main parameters in measuring customer loyalty. It is similar with what was expressed by Muhammad Idris in his article on Initiated the Service Excellence of Islamic Banking (2012) where one main reason why customers choose a bank is the quality of the services provided by the bank.

Several previous studies used as a comparison and reference in this study; for example, the research conducted by Henderson (2008) with the title Factors Affecting Customer Loyalty of Islamic Banks. This research was conducted in Bandar Lampung with the criteria of respondents that customers have accounts in islamic bank and have already become a customer with a minimum period of 1 year. The independent variables used were the application of Islamic values, trust, and customer satisfaction of the Islamic banks by using Servqual method, and the dependent variable is customer loyalty of Islamic banks. The results of these studies shows that overall the independent variables significantly influence the formation of customer loyalty.

Business banking service according to the Dwi (2003) is a business that is easily replicable by the competitors, and the technology used will be easily imitated by its competitors. Also, with the products produced, it can be said that the banking products have homogeneous characteristics. The number of bids of a product of the banking industry will make people have a vast selection to determine which bank will be used. This will affect the attitude of customers in determining and addressing the services provided by the bank, and the extent to which the customers will feel satisfied with the services of the bank. Products and technology can be imitated, but the manner and attitude of serving the customer will not be able to be imitated easily, so that the banking industry is required to better understand the desires and needs of the customers. From this study, several research questions can be formulated as follows: What factors do affect the brand image of Islamic banks and the customer loyalty of Islamic banks in Bogor City?; What Managerial implications can be given to the company based on the results of the research?.

\section{METHODS}

The data taken to complete the writing of this thesis were primary data. The study was conducted for 1 month starting from October to November 2017. The institutions studied include sharia banks in Bogor City i.e. Bank Muamalat, BNI Syariah, Bank Permata Syariah, Bank BTN Syariah. The survey was conducted on customers who were conducting transactions at the Tellers or the Customer Service of the banks.

The number of samples used in this study followed the guidelines developed by Ferdinand (2002), depending on the number of indicators of all latent variables. The number of samples was 200 respondents because based on Ferdinand (2002) the size of the tools used in the study using the method of SEM between 100 200 represents the total sampling population that is unknown. 
The respondents were taken as samples using the technique of non-probability sampling method with convenience sampling. This technique is a sampling technique which is carried out with consideration of the ease in which the respondents were customers conducting transactions through a front liner.

There are two variables used in the measurement with SEM model, where latent variables can serve as exogenous variables and endogenous variables. Exogenous variables are independent variables that affect the dependent variable while the endogenous variable is a dependent variable which is influenced by the independent variables. There were 36 exogenous and endogenous variables used, and the indicator variables can be seen in Table 2 .

\section{Structural Equation Model (SEM)}

To explain the influence of dimensions of the components of service quality and funding product quality to brand images and customer loyalty and too see the relationship among the variables in these measurements, the approach of SEM was used. SEM is used to formulate a pattern resulting from the pattern of linkages and causality of the various indicator variables or latent variables. This analysis was used to analyze the causal relationship (Wijayanto, 2008) where the SEM analysis was carried out to explain thoroughly the relationship between variables in a study. The structural Model of SEM in this study can be seen in Figure 2.

There are many factors that can be used as a reason for customers to remain loyal to financial institutions, one of which is the quality product and service excellence. Service excellence is a concern to our customers by providing the best service to facilitate the ease, fulfilling needs and realizing the satisfaction that they are always loyal to the company (Wirtz and Lovelock, 2004). To determine the level of service quality of Islamic banking in Bogor City, it is necessary to do a survey to the customers of Islamic banks. The quality of these services will be measured by looking at the affecting dimensions i.e. Reliability, Responsiveness, Assurance, Empathy, and Tangible. From the research framework of this study (Figure 3), the research hypothesis was formulated as follows: H1 (The quality of services influences the brand image of sharia banks in Bogor City); H2 (The quality of products influences the brand image sharia banks in Bogor City); H3 (The quality of services influences the customer loyalty of sharia banks in Bogor City); H4 (The quality of products influences the customer loyalty of sharia banks in Bogor City); H5 (The brand image influences the customer loyalty of sharia banks in Bogor City).

\section{RESULT}

The level of competition highly makes every company able to show the advantages and characteristics of products and services. The competition will indirectly affect company policy in an effort to maintain market share that has been owned. Efforts to maintain customer loyalty and good image of the brand image of the company are the main things that should be made by the company. The influence of a brand image of Islamic products which is bad to customers will give a bad image to the sharia bank, and if this happens, the customer will switch from the sharia bank to another bank that has a better brand image.

\section{Profile of Respondents' Demography}

The respondents based on the gender showed that the majority of customers were women i.e. 101 customers whereas there were 99 male customers of the 200 respondents. The average age of the customers was 21-30 years of 95 people and 31-40 years of 77 people. This suggests that the customers of sharia bank are customers with productive ages where the status of 118 customers was married, and 140 people had a bachelor degree. Type of work is one of the attributes has an indirect effect in the social class in society and can affect a person's lifestyle. Customers of sharia bank in Bogor City mostly work as private employees and have an average income between Rp3,000,000 and $\mathrm{Rp} 5,000,000$. These data provide information that the customers of Islamic banks in general have an income above the minimum wage. 
Table 2. Variables of the research

\begin{tabular}{|c|c|c|c|}
\hline Construct variables & & Exogenous variables & References \\
\hline \multirow[t]{7}{*}{ Tangible } & KL1 & & \\
\hline & KL1.1 & Location of office building & Bahia and Natel (2000) \\
\hline & KL1.2 & Waiting room facility & Othman and Owen (2001) \\
\hline & KL1.3 & Praying room facility & Tjiptono (2001) \\
\hline & KL1.4 & Parking facility & Tjiptono (2001) \\
\hline & KL1.5 & Transaction device & Yazid (2005) \\
\hline & KL1.6 & Employee appearance & Bahia and Natel (2000) \\
\hline \multirow[t]{5}{*}{ Realibility } & KL2 & & \\
\hline & KL2.1 & Reputation & \\
\hline & KL2.2 & Product fitness & Hanan and Karp (2001) \\
\hline & KL2.3 & Time accuracy & \\
\hline & KL2.4 & Complaint handling & Bahia and Natel (2000) \\
\hline \multirow[t]{5}{*}{ Responsivenes } & KL3 & & \\
\hline & KL3.1 & Service- level agreement/service velocity & Hanan and Karp (2001) \\
\hline & KL3.2 & Employee alertness & Hanan and Karp (2001) \\
\hline & KL3.3 & Employee agility & Hanan and Karp (2001) \\
\hline & KL3.4 & Employee ability & Hanan and Karp (2001) \\
\hline \multirow[t]{5}{*}{ Assurance } & KL4 & & \\
\hline & KL4.1 & Employee behaviour & Hanan and Karp (2001) \\
\hline & KL4.2 & Employee understanding & Caruana (2002) \\
\hline & KL4.3 & Service operational procedure & Hanan and Karp (2001) \\
\hline & KL4.4 & Verbal communication & Hanan and Karp (2001) \\
\hline \multirow[t]{5}{*}{ Emphaty } & KL5 & & \\
\hline & KL5.1 & Personal attention & Hanan and Karp (2001) \\
\hline & KL5.2 & Apologizing & Hanan and Karp (2001) \\
\hline & KL5.3 & Employee attention & Hanan and Karp (2001) \\
\hline & KL5.4 & Hospitality & Hanan and Karp (2001) \\
\hline \multirow[t]{6}{*}{ Product Quality } & KP1 & Performance/product usage & Cronin and Preis (2008) \\
\hline & KP2 & Feature & \\
\hline & KP3 & Margin/profit-loss sharing & \\
\hline & KP4 & Program & \\
\hline & KP5 & Sharia compliance & Othman and Owen (2001) \\
\hline & KP6 & Accessbility (ATM, m-Banking, e-Channel & Rifai (2011) \\
\hline \multirow[t]{4}{*}{ Brand Image } & Y1 & Sharia brand & Kotler (2004) \\
\hline & $\mathrm{Y} 2$ & Islamic value on product & Kotler (2004) \\
\hline & Y3 & Reputation & Maski (2010) \\
\hline & Y4 & Attraction & Nawi et al. (2013) \\
\hline \multirow[t]{4}{*}{ Customer Loyalty } & $\mathrm{Z} 1$ & Positive telling & Hendra (2008) \\
\hline & $\mathrm{Z} 2$ & Recommendation to friends & \\
\hline & $\mathrm{Z3}$ & Retransaction & Lovelock and Wright (2002) \\
\hline & $\mathrm{Z} 4$ & Endurance not to leave & \\
\hline
\end{tabular}




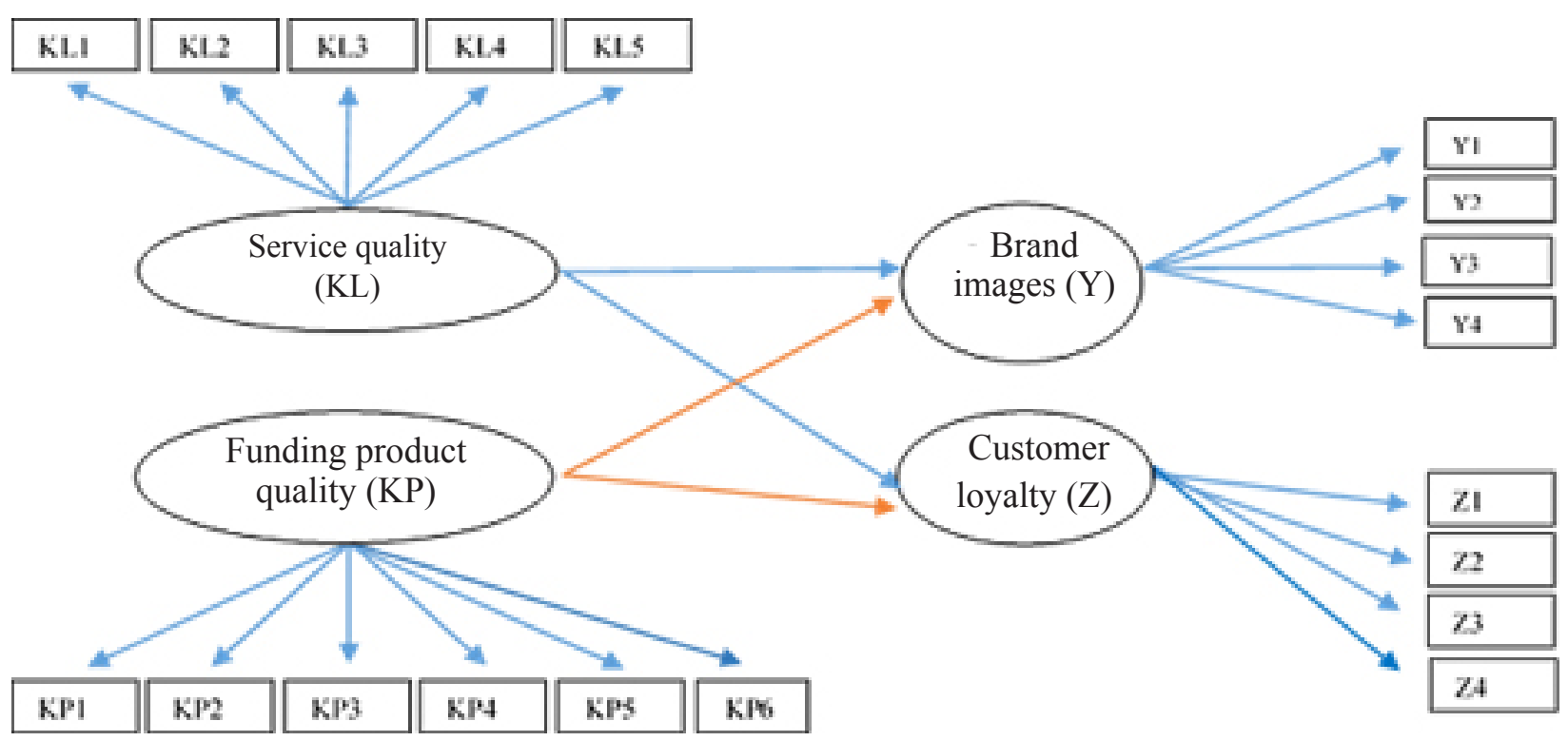

Figure 1. Flow diagram of SEM model

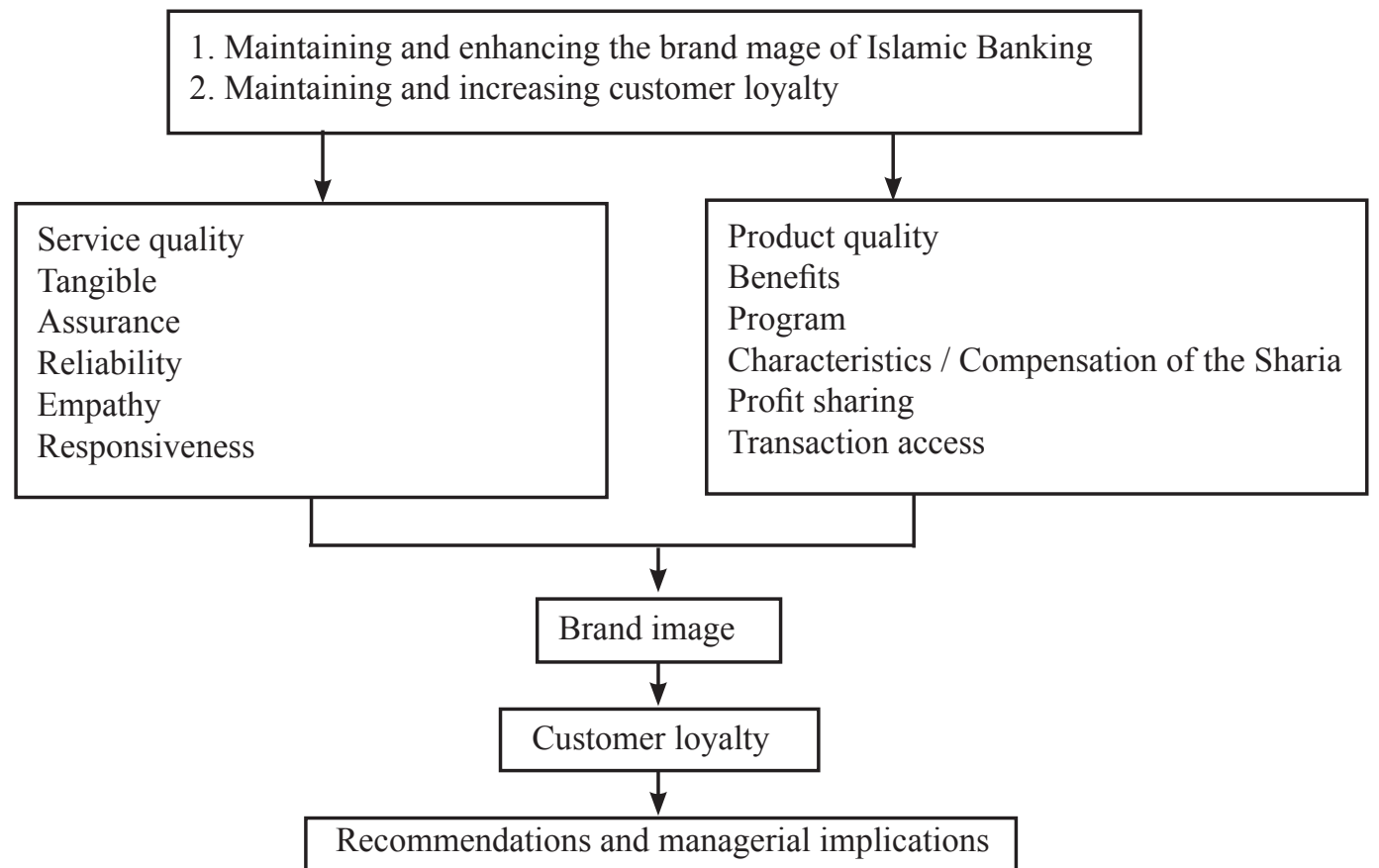

Figure 2. Research framework

\section{Profile of Respondent}

Customers know the Islamic banks through office buildings of Islamic banks located on the main street. This indicates that the layout of the branch office or branch is strategic so as to attract the public to know what sharia bank is better and to become a customer of Islamic banks. Average customers of Islamic banks still have one account in a conventional bank with a percentage of $41 \%$. This shows that the society has not yet completely left the conventional banks because of personal reasons. 27 of the customers have accounts only in the Islamic bank. Customers who use the islamic bank as the first choice to perform financial and banking transactions reached $69 \%$. This shows that the society has started to gradually realize the importance of transactions through Islamic banking. 
The Factors Affecting the Brand Image of Islamic banks and Customer Loyalty of Islamic banks

This study used all variables associated with the operation of Islamic banking because Islamic banks and had characteristics which are not possessed by the conventional banks where they apply the Islamic principles in their operations. The other reasons are because there are a lot of instruments based on Islamic values that need to be developed because they are associated with Islamic law where it is fitting that every believer should adhere to all the rules that have been defined by God. This is in accorandce with the word of God on the QS. Al-Ahzab; verse 36, which means "It is not for a believing man or a believing woman, when Allah and His Messengers have decided a matter, that they should [thereafter] have any choice about their affair. And whoever disobeys Allah and His Messenger has certainly strayed into clear error".

The content of the verse can be interpreted that Islam has set up all human life clearly and all of the existing rules as the case with the activities of the economic transactions. The banking transaction recommended by Islam is a transaction that is free from the elements of maysir, gharar, and riba. Sharia banking should have different characteristics both for its products and banking service operation so the label 'sharia' which is inherent in the bank can give a positive image and an Islamic character so that customers feel confident and comfortable in performing their transactions, thus increasing customer loyalty from muslim and non-muslim customers. This is in accorandce with the results of the research conducted by Farid (2012) titled Analysis of the Level of Customer Satisfaction of Non-Muslims on the Service Quality of Sharia Bank in Meand City in which the results show that the value of the CSI (Customer Satisfaction Index) amounted to $68.9 \%$, which means that non-muslim customers' feel reasonably satisfied with the service quality of the bank. According to Hair et al. (1998) in Wijanto (2008), evaluation on the level of compatibility of the data with the model was conducted through several stages as follows:

\section{Overall model fit}

This study used Structural Equation Modelling (SEM) contained in Lisrel program where this method of testing simultaneously consisted of independent and the dependent variables.
After passing the test of validity and reliability, the compatibility of the data with the overall model called Goodness of Fit (GOF) was analyzed. This test evaluated whether the model produced is good fit or not. The results of test calculations are as follows:

- The value of the Standardized RMR is 0.027 , and this is 0.05 , so it shows that the fitness value of the whole model is good fit.

- The value of RMSEA is 0.080 and this is 0.08 , so it shows that the fitness value of the whole model is good fit.

- The value of GFI is 0.98 and this is 0.90 , so it shows that the fitness value of whole model is good fit.

- The value of AGFI is 0.98 and this is 0.08 , so it shows that the fitness value of whole model is good fit.

- The value of CFI is 1.00 and this is $\geq 0.90$, so it shows that the fitness value of whole model is good fit.

- The value of NFI is 1.00 and this is $\geq 0.90$, so it shows that the fitness value of whole model is good fit.

- The value of RFI is 1.00 and this is $\geq 0.90$, so it shows that the fitness value of whole model is good fit.

\section{Measurement of Model Fit}

The value of VE for each latent variable that has a value of $>0.5$ is highly recommended. Based on table 5 above, the value and reliability of the Physical Evidence VE is less than 0.5 but the value of Construct of Reliability is more than 0.6 ; therefore, the convergent validity of the latent invalid constructs can still be said to be adequate (Fornell and Larcker, 1981). The VE values of Responsiveness, Assurance, Empathy, Loyalty, Brand Image, product quality, and service quality are over 0.5 , indicating that every indicator variable is valid to measure its invalid latent constructs.

Suitability criterion of the measurement model is measured based on the validity of the indicator variables to the latent variables. An indicator variable is said to be valid when it has a value of standardized loading factor (Figure 3) more than the loading factor limit which can still be tolerated i.e. $\geq 0.50$ (Igbaria et al. 1997) and has a t-value above 1.96 (Wijanto, 2008). Based on the results on the diagram of the standardized loading factor and the diagram of the t-value, it can be seen that all variables meet the condition of validity indicated by the value of standardized loading factor more than 0.5 and the $t$-value above 1.96 (significant). 
Structural Model Result

Based on the results of refined SEM relationships between variables provide the results as shown in the following Table 3. From all the results of the calculation of these indicators produce data seen in Figure 4 The Diagram of the T-Values and provide information as follows: H1 (Variable of service quality affects the brand image); H2 (Variable product quality affects the brand image); H3 (Variable of service quality do not affect customer loyalty); H4 (Variable of product quality affects the customer loyalty); H5 (Variable of brand image affects customer loyalty).

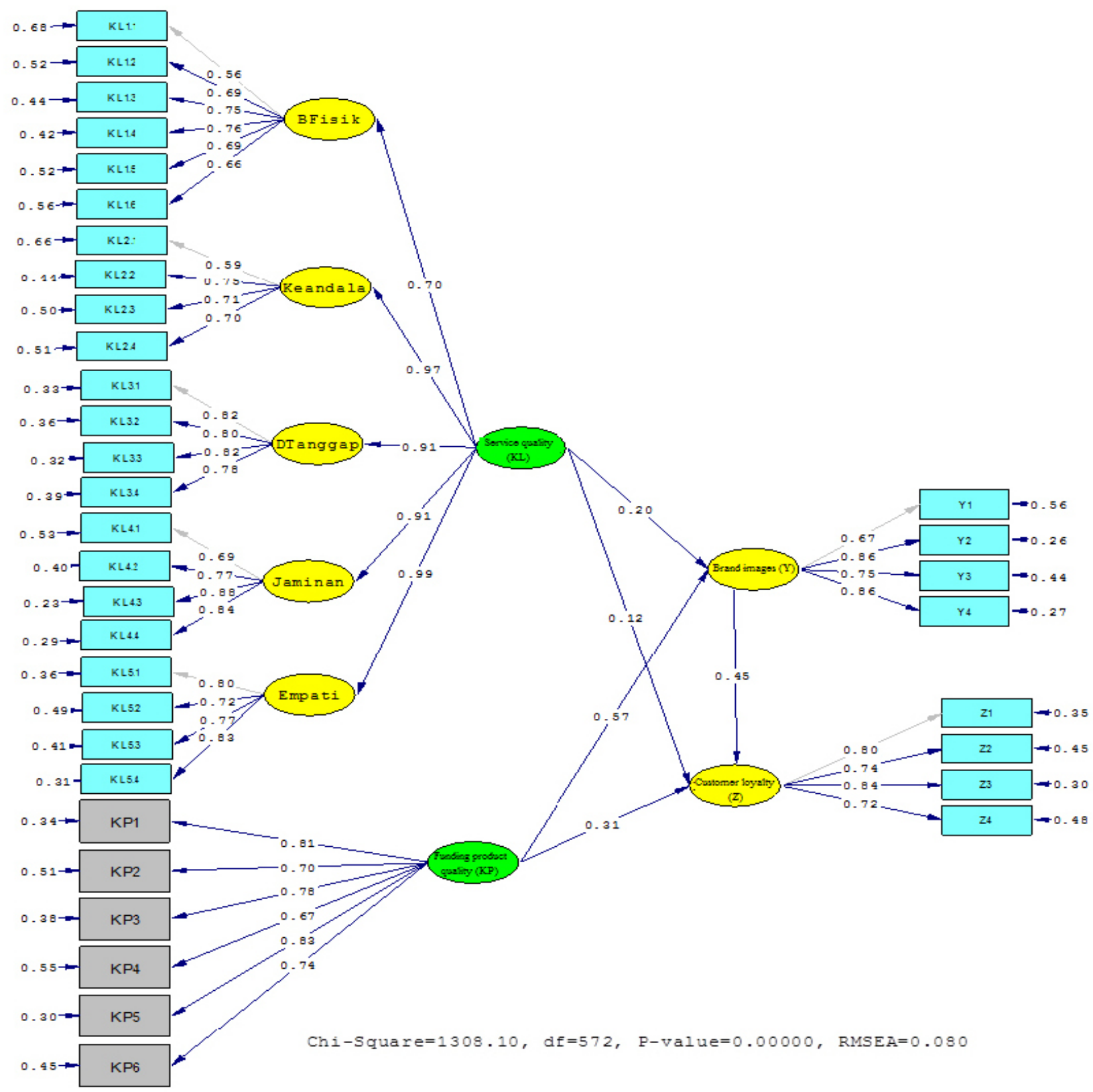

Figure 3 Diagram of standardized loading

Table 3. Result of Processed SEM Model

\begin{tabular}{lccc}
\hline Relationships among variables & Coefficient Path & $\mid$ t-hit $\mid$ & Conclusion \\
\hline Service Quality $\rightarrow$ Brand Image & 0.20 & 2.44 & Significant \\
Product Quality $\rightarrow$ Brand Image & 0.57 & 6.14 & Significant \\
Service Quality $\rightarrow$ Loyalty & 0.12 & 1.28 & Insignificant \\
Product Quality $\rightarrow$ Loyalty & 0.31 & 2.39 & Significant \\
Brand Image $\rightarrow$ Loyalty & 0.45 & 2.11 & Significant \\
\hline
\end{tabular}




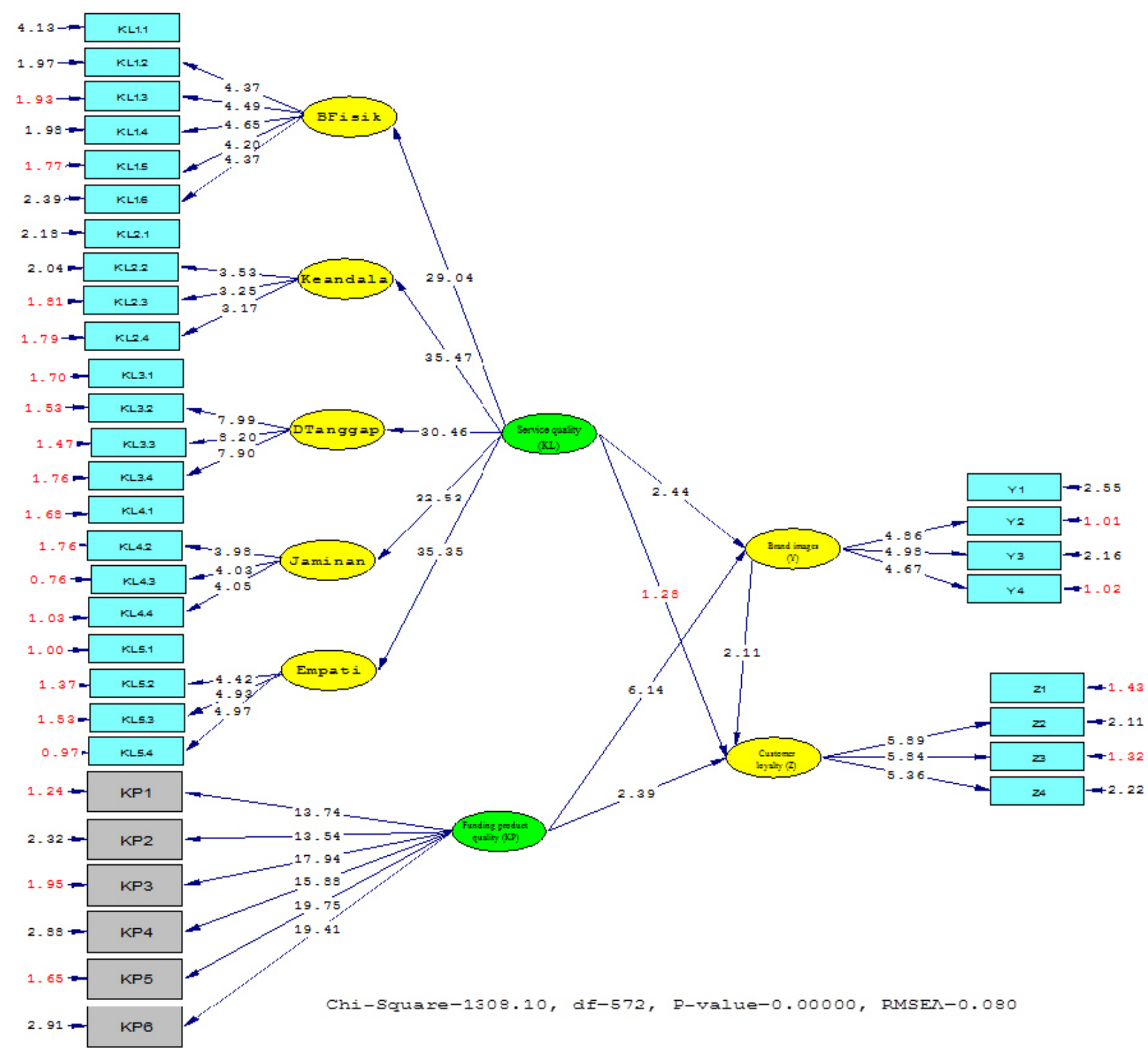

Figure 4. Diagram of T-Values

\section{The Service Quality Variable Positively Affects the Brand Image}

A service company always has a close relationship with the quality of service, and one example is the company's Islamic banking service. According to Kotler in Tjiptono (2001), service is any act or acts that can be offered by one party to another one, and this service is essentially intangible (not a physical shape) and does not generate ownership of something. Appearance of physical infrastructure and facilities of the company and the state of the surrounding environment are tangible evidence of the services provided by the company. According to Yazid (2008), facility is part of the physical evidence of a service company, where the physical evidence includes all aspects of the physical facilities of the organization or the servicescape that includes the environment created, the work of human, and physical environment services. Servicescape has a role of becoming a one unit or one package of services offered in a different way by offering a product. Thus, the servicescape is one appearance of tangible of a service company, and it is highly important in shaping the expectations of consumers.

\section{Service Quality Variable Positively Affects the Brand Image}

Islamic Bank has been developed based on principles that do not allow a separation between temporal things and religion. This principles require adherence to the sharia as the basis of all aspects of life. This compliance is not only in terms of ritual worship but a business transaction involving products produced by the Islamic 
bank that must be in accordance with the teachings of sharia. Funding products in Islamic banks have features different from funding products in conventional banks. For example, the presence of the auto debit of zakat and waqf in savings products, where customers can choose how much zakat will be deducted each month. The results of the research are supported also by the results of the research conducted by Omer (1992) which leads to a conclusion that the religious factor as well as the products of Islamic banking which is interest-free (riba) is very influential on the attitude of customers towards Islamic banks. This condition is also supported by the opinion (Al-Serhan, 2017) that the brand of Islamic Branding is halal as elements of the brand do not only describe the function and interpretation of the materials of products but are also able to describe aspects of the market conditions, halal supply chain management (Tieman, 2011), packaging, and logo of halal (Talib and Johan, 2012).

\section{Brand Image Variable Positively Affects Customer Loyalty}

Brand Image of Islamic Banking is not only influenced by the quality of the service, but the quality of the products also affects the brand image of the bank. The quality of these products are measured by how they benefit customers and the bank itself, and the characteristics of the products are certainly very different from those of conventional banks. The system for the results given to the customer is in accorandce with the agreement at the beginning of the opening of the account. The program of awarding prizes does not violate Islamic laws, the sharia compliance on any product offered to customers is exercised, and the ease of transacting via electronic channels, such as ATMS, m-banking, and e-banking can be obtained. The presence of electronic transaction chanel proves that the Islamic bank is a modern bank which continues to provide ease of transaction to customers. Both product quality and brand image provide a positive influence on customer loyalty. This is in accorandce with the opinion of (Fatimah, 2014) who says that brand loyalty is similar to the commitment of consumers toward a brand, which is the result of consumer confidence.

\section{Quality product variable positively affects the customer loyalty}

Variables forming customer loyalty are measured by four indicators. Firstly, customers will deliver positive things on Islamic banks to their friends, relatives, and others who already know the bank or those who do not know yet. Secondly, customers will be happy to recommend the products and services of Islamic banks to other people. Thirdly, the customers will also perform recurring transactions with Islamic banks, and finally, the customers are committed not to close their accounts in Islamic banks. This suggests that customers of Islamic banks will continue to invite other people to deal with sharia, and they will have their reward from Allah as in the hadith narrated by Imam Muslim, indicating that "anyone who gives instructions to others in terms of goodness then he or she will obtain a reward like the reward of the people who do this." The hadith is reinforced by the word of God contained in the QS. Ali Imron: 3 verse 104, meaning that "let there be [arising] from you a nation inviting to [all that is] good, enjoying what is right and forbidding what is wrong, and you will be successful.

In the banking industry, the resulted product is intangible so that the size of the quality can be felt in the aspect of service when performing transactions and when the product is used in a certain period of time and provides benefits for customers who use the product and services of islamic banking. The quality of the product funding of islamic banking must be in accordance with the criteria mentioned by the FSA in the OJK Circular Letter No. 36/SEOJK.03/2015: Islamic banking products should be in accordance with Islamic values that are free from elements of riba, gharar, and maysir. Customers have already felt the benefits from the consumption of products of Islamic banking both financially and nonfinancially, and it will affect the customer loyalty to reutilize the existing products to the needs of personal and corporate financial transactions.

Customer loyalty to this product is the effect of the end of a purchase, where customers will be committed to make multiple purchases and will always use the other products if the company issues a new product. Another effect of this loyalty is the fact that customers will provide their recommendations to others, have the desire to tell all the positive things about the company and are willing to pay dearly (Palitati, 2007).

\section{Managerial Implications}

The data are enough to explain that Syaria Bank is suggested to be able to do innovations and product development funding periodically in accordance with 
the development of the banking industry, in particular, the sharia banking industry. Innovations and product development funding are expected to continue promoting the side of the Islamic teachings so that customers feel more confident with the advantages of products from the Islamic banking. In corporate banking, the sharia bank should also be able to develop features that are attached on funding products so that Islamic banking can still compete with the conventional banks. The services provided by sharia bank should have a characteristic that is not owned by a conventional bank, so that customers can feel the service in accorandce with its sharia logo. The staff of the bank especially the officers of the front liners should be able to provide a 'plus' service, and the officer must serve as a medium in giving da'wah in sharia economy.

\section{CONCLUSIONS AND RECOMMENDATIONS}

\section{Conclusions}

The results of this study indicate that the variables having positive effects on brand image include service quality and product quality. That means that the qualities of service and product reflect the identity and hallmark of the company so that the services owned by a company cannot be easily imitated by competitors, and this is the image of the company. Another thing that affects the brand image is the quality of product, especially the quality of product funding of a sharia bank. The products are free from the elements of maysir, gharar, and riba based on the Qur'an and Hadith and that becomes the hallmark of sharia banks where products owned by sharia bank are not owned by a conventional bank.

The other things that give positive influences on customer loyalty are product quality and brand image of Islamic banks. Customers will be more loyal if they perceive that the product purchased is a product meeting the needs of right and mandatory financial transactions and bring blessing for anyone who consume it.

\section{Recommendations}

This research is still far from perfect and still used simple variables so that the results have not been optimal; therefore, further research should be added other variables which further leads to the values of sharia compliance for the product or service. This study only took a sample of 200 respondents in Bogor City spread in 4 Islamic banks, 50 of whom were taken from each Sharia bank. Therefore, it is necessary to conduct a research in the entire sharia bankin Bogor City so that the optimum result can be obtained and provide in-depth information related to customers of whirlpool of sharia and the Islamic banks. This research is still limited to the customer funding only so that the information obtained was only derived from what is perceived by customer funding and no information on customer financing was obtained.

\section{REFERENCES}

Al-Serhan. 2017. The influence of transactionality on consumers boycotting behaviour. Journal Islamic Marketing and Branding 2(3).

Antonio S. 2001. Bank Syari'ah dari Teori ke Praktek. Jakarta: Gema Insani.

Bahia K, Natel J. 2000. A reliability and valid measurement scale for the pereived quality of banks. The International Journal of Bank Marketing 18(2):84-91. https://doi. org/10.1108/02652320010322994.

Caruana A. 2002. Service loyalty: the effects of service quality and the mediating role of customer satisfaction. European Journal of Marketing 36(7/8):811-828. https://doi. org/10.1108/03090560210430818.

Dwi JM. 2003. Analisis kualitas layanan nasabah Bank BNI Cabang UI Depok antara harapan dan persepsi [thesis]. Bogor: MMA-IPB.

Fatimah. 2014. Pengaruh kesadaran merk, persepsi kualitas, asosiasi merk, dan loyalitas merk terhadap pembelian pelembab wardah pada konsumen Al yasini Market. Jurnal Sketsa Bisnis 1(2):52-70.

Farid M. 2012. Analisis tingkat kepuasan nasabah non muslim terhadap layanan bank syariah. Jurnal Ekonomi dan Keuangan 1(11):46-56.

Ferdinand A. 2002. Structural Equation Modeling dalam Penelitian Manajemen Aplikasi Model. Jakarta: Gramedia.

Fornell C. 1992. A national customer satisfaction barometer: the swedish experiene. Journal of Marketing Abi/Inform 56 (1):6-21. https://doi. org/10.2307/1252129.

Hendra. 2008. Faktor - faktor yang mempengaruhi loyalitas nasabah bank syari'ah [thesi]. Depok: Universitas Indonesia. 
Ismail R. 2014. Penagaruh kualitas layanan, kualitas produk and kepuasan nasabah sebagai prediktor dalam meningkatkan loyalitas nasabah. Jurnal Organisasi and Manajemen 10(20:179-196.

Iqbaria M, Zinatelli N, Cragg P, Cavaye A. 1997. Personal computing acceptence factors in small firms: a strusctural equation model. Journal of MIS Quartely 21(3):279-305.

Karim A. 2006. Bank Islam Analisis Fiqih and Keuangan. Jakarta: Raja Grafindo Persada.

Keller KL. 2003. Startegic brand management: building measurin, and imagine brand equity. Journal of Brand Management 14(5):380-395.

Maski G. 2010. Analisis keputusan nasabah menabung: pendekatan komponen dan model logistik studi pada bank syariah di Malang. Journal of Indonesian Applied Economics 4(1): 43-57.

Omer. 1992. The Implications of Islamic beliefs and practice on the Islamic Financial Institutions in the UK (Case Study: of Albara-ka International Bank UK) [thesis]. Loughborough: Economics De-partment, Loughborough University.
Palitati. 2007. Pengaruh Nilai Pelanggan, Kepuasan terhadap Loyalitas Nasabah Tabungan Perbankan di Sulawesi Selatan [thesis]. Kendari: Universitas Haluoleo Kendari.

Wirtz, Lovelock. 2004. Service marketing people, technology, and strategy. Seventh Edition. Working Paper.

Thalib, Johan. 2012. Issues in halal packaging: a conceptual paper. Journal of International Business and Management. 5:94-98.

Tjiptono F. 2001. Prinsip-prinsip Total Quality Service. Yogyakarta: Penerbit Andi.

Yousuf M, Jusoh W. 2014. Islamic branding: the understanding and perception. Journal Social and Behaviour Sciences 130:179-185.

Wijayanto SH. 2008. Structural Equation Modelling dengan Lisrel 8.8. Yogyakarta: Graha Ilmu.

Yazid. 2008. Pemasaran Jasa: Konsep Dan Implementasi I. Yogyakarta: Ekonisia Fakultas Ekonomi. 